\title{
Association of genetic variants in the CART gene with glioma susceptibility in a Chinese population
}

\author{
Liang Wang ${ }^{1, *}$, Gang $\mathrm{Li}^{1, *}$, Nan Liu ${ }^{2, *}$, Zhen Wang ${ }^{2}$, Xiaoshan $\mathrm{Xu}^{2}$, Jing $\mathbf{Q}{ }^{2}$, Dongni \\ Ren $^{2}$, Pengxing Zhang ${ }^{2}$, Yongsheng Zhang ${ }^{3}$ and Yanyang $\mathbf{T u}^{2}$ \\ ${ }^{1}$ Department of Neurosurgery, Tangdu Hospital, Fourth Military Medical University, Xi'an, China \\ ${ }^{2}$ Department of Experimental Surgery, Tangdu Hospital, Fourth Military Medical University, Xi'an, China \\ ${ }^{3}$ Department of Administrative, Tangdu Hospital, Fourth Military Medical University, Xi'an, China \\ * These authors have contributed equally to this article \\ Correspondence to: Yanyang Tu, email: tu.fmmu@gmail.com \\ Yongsheng Zhang, email: zhangys_td@163.com
}

Keywords: CART; gliomas; polymorphism, genetic susceptibility

Received: June 29, $2016 \quad$ Accepted: August 26, 2016

Published: August 31, 2016

\section{ABSTRACT}

\begin{abstract}
Glioma, which is a rare and highly fatal brain cancer, has been studied for many decades. However, only a few etiological factors have been established. Genetic factors play an essential roles in the development of gliomas and are key component of preventive oncology. However, only a small proportion of the genetic effect has been yet established. In current study, we systematically evaluated whether genetic variants of CART gene, which generates multiple biologically active peptides, contribute to susceptibility of gliomas among Chinese people with a two-stage, casecontrol study. In stage I, we found rs2239670 (Allele A vs G: OR $=1.33 ; 95 \% \mathrm{CI}=$ 1.03-1.70; $P=0.026$ ) and rs11575893 (Allele $T$ vs $C$ : $O R=1.29 ; 95 \% C I=1.01-1.65$; $P=0.040$ ) were significantly associated with increased glioma susceptibility. Then the two SNPs were significantly replicated in an independent stage. When pooled together, both rs2239670 (Allele A vs G: OR $=1.27 ; 95 \%$ CI $=1.10-1.46 ; P=0.001$ ) and rs11575893 (Allele T vs C: $O R=1.25 ; 95 \% C I=1.09-1.45 ; P=0.002$ ) were significant associated with increased glioma susceptibility. Our data suggest that the genetic variants in the CART gene potentially predispose their carriers to gliomas.
\end{abstract}

\section{INTRODUCTION}

Gliomas make up approximately $80 \%$ of all malignant brain tumors [1]. Although relatively uncommon in the general population, gliomas owns high morbidity and mortality [2-5]. In China, the estimated incidence and mortality numbers of brain tumors, which were mainly composed by gliomas, are 101.6 and 61.0 thousands in 2015 , respectively [6], while the correspondent numbers in United States are 27,770 and 16,050 in 2016, respectively [7]. Gliomas were composes of several subtypes, mainly including Glioblastomas, which account for approximately 60 to $70 \%$, anaplastic astrocytomas, which account for 10 to $15 \%$, and anaplastic oligodendrogliomas and anaplastic oligoastrocytomas, which account for $10 \%$ [3, 8-11]. To present, only a small proportion of the genetic factors for gliomas has been yet established, including results of familial studies, candidate gene studies, and genome- wide association studies (GWASs) [12-16]. Understanding of the genetic basis is a key component of preventive oncology.

Cocaine and amphetamine regulated transcript (CART) gene encodes cocaine and amphetamine regulated transcript prepropeptide (CARTPT), which generates multiple biologically active peptides [1719]. These peptides play an important role in cancers, schizophrenia, alcohol use disorders, nicotine dependence, methamphetamine dependence, and obesity [20-25]. Genetic association studies could provide solid evidence for the potential role of CART gene in human malignant gliomas. However, no studies have evaluated that whether genetic variants of CART contribute to risk of gliomas. In current, we performed a two-stage, case-control study to investigated the association between tag SNPs in the CART gene and gliomas susceptibility among Chinese population. 
Table 1: Comparison of gliomas patients and controls by selective characteristics

\begin{tabular}{|l|l|l|l|l|l|l|}
\hline \multicolumn{2}{|l}{ Stage I } & \multicolumn{2}{l|}{ Stage II } \\
\hline Variables & Cases (n=400) & Controls (n=400) & P value & Cases (n=800) & Controls (n=800) & $\boldsymbol{P}$ value \\
\hline Age (years) & $48.2 \pm 3.8$ & $48.5 \pm 3.3$ & 0.233 & $45.3 \pm 4.2$ & $45.1 \pm 4.7$ & 0.370 \\
\hline Gender (male) & $244(61.0 \%)$ & $248(62.0 \%)$ & 0.771 & $480(60.0 \%)$ & $468(58.5 \%)$ & 0.542 \\
\hline Family history of cancer & $86(21.5 \%)$ & $75(18.8 \%)$ & 0.332 & $160(20.0 \%)$ & $131(16.4 \%)$ & 0.060 \\
\hline Smoking status & & & & & & \\
\hline Ever & $100(25.0 \%)$ & $97(24.2 \%)$ & 0.806 & $162(20.2 \%)$ & $132(16.5 \%)$ & 0.053 \\
\hline Never & $300(75.0 \%)$ & $303(75.8 \%)$ & & $638(79.8 \%)$ & $668(83.5 \%)$ & \\
\hline Alcohol status & & & & & & \\
\hline Ever & $114(28.5 \%)$ & $104(26.0 \%)$ & 0.435 & $238(29.8 \%)$ & $160(20.0 \%)$ & $P<\mathbf{0 . 0 0 1}$ \\
\hline Never & $326(81.5 \%)$ & $336(84.0 \%)$ & & $562(70.2 \%)$ & $640(80.0 \%)$ & \\
\hline
\end{tabular}

Table 2: Association between CART gene polymorphisms and the risk of gliomas in stage I

\begin{tabular}{|c|c|c|c|c|c|c|c|c|}
\hline \multirow[b]{2}{*}{ SNPs } & \multirow[b]{2}{*}{ Subject } & \multicolumn{3}{|c|}{ Genotype (N) } & \multicolumn{3}{|l|}{ OR $(95 \% \text { CI })^{1}$} & \multirow[b]{2}{*}{$\boldsymbol{P}$ value } \\
\hline & & 11 & 12 & 22 & 2 vs 1 & 12 vs 11 & 22 vs 11 & \\
\hline \multirow[t]{2}{*}{ rs2239670 } & Case & 257 & 115 & 28 & $1.33(1.03-1.70)$ & $1.20(0.88-1.65)$ & $1.91(1.02-3.57)$ & 0.026 \\
\hline & Control & 280 & 104 & 16 & & & & \\
\hline \multirow[t]{2}{*}{ rs3846659 } & Case & 250 & 128 & 22 & $1.12(0.88-1.43)$ & $1.10(0.81-1.50)$ & $1.28(0.67-2.43)$ & 0.353 \\
\hline & Control & 261 & 121 & 18 & & & & \\
\hline \multirow[t]{2}{*}{ rs11575893 } & Case & 246 & 130 & 24 & $1.29(1.01-1.65)$ & $1.24(0.92-1.68)$ & $1.75(0.91-3.40)$ & 0.040 \\
\hline & Control & 270 & 115 & 15 & & & & \\
\hline \multirow[t]{2}{*}{ rs6894772 } & Case & 285 & 105 & 10 & $1.05(0.80-1.38)$ & $1.12(0.81-1.54)$ & $0.85(0.36-2.00)$ & 0.729 \\
\hline & Control & 292 & 96 & 12 & & & & \\
\hline
\end{tabular}

${ }^{1}$ adjusted for Age, gender, family history of cancer, smoking status and alcohol status

\section{RESULTS}

\section{Demographic characteristics of the subjects}

In stage I, a total of 400 gliomas patients and 400 healthy control were recruited, while 800 gliomas patients and 800 healthy control were recruited in stage II. Table 1 shows the comparison of gliomas patients and controls by selective characteristics in both stage I and stage II. No significant difference in the distribution of age, gender, family history of cancer, and smoking status was found between the gliomas patients and healthy controls in two stages $(P>0.05)$. Only the gliomas patients are more likely to be drinkers in stage II $(P<0.001)$.

\section{Associations between CART gene polymorphisms and glioma susceptibility in the discovery stage}

According to the selection criteria, four tagSNPs (rs2239670, rs3846659, rs11575893, and rs6894772) are selected using SNPinfo. Table 2 presents the genotype frequencies of the selected SNPs and their associations with glioma susceptibility. None of the genotype distributions for the four tag SNPs departed from the HWE $(P>0.05)$. Our results showed that rs 2239670
(Allele A vs $\mathrm{G}: \mathrm{OR}=1.33 ; 95 \% \mathrm{CI}=1.03-1.70 ; P=$ 0.026 ) and rs 11575893 (Allele $\mathrm{T}$ vs $\mathrm{C}: \mathrm{OR}=1.29 ; 95 \%$ $\mathrm{CI}=1.01-1.65 ; P=0.040)$ were significantly associated with increased glioma susceptibility. Compared with the carriers of genotype GG of rs2239670, those of genotype AA $(\mathrm{OR}=1.91 ; 95 \% \mathrm{CI}=1.02-3.57)$ had significantly increased glioma susceptibility. However, no significant associations were found for rs3846659 and rs6894772.

\section{Validation analysis of the association between selected CART SNPs and glioma susceptibility}

To validate the results above, we evaluated the associations of CART rs2239670 and rs11575893 with glioma susceptibility was evaluated in stage II (Table 3). The genotype distribution of rs2239670 and rs11575893 in controls were also consistent with the HWE $(P>0.05)$. The positive trend for $\mathrm{rs} 2239670\left(\mathrm{OR}_{\text {trend }}=1.24 ; 95 \%\right.$ $\mathrm{CI}=1.04-1.47 ; P=0.015)$ and $\mathrm{rs} 11575893\left(\mathrm{OR}_{\text {trend }}=\right.$ $1.23 ; 95 \% \mathrm{CI}=1.04-1.47 ; P=0.018$ ) was significantly replicated in Stage II. When pooled the results of the two stages together, both rs2239670 (Allele A vs G: OR = 1.27; $95 \% \mathrm{CI}=1.10-1.46 ; P=0.001$ ) and rs 11575893 (Allele T vs $\mathrm{C}: \mathrm{OR}=1.25 ; 95 \% \mathrm{CI}=1.09-1.45 ; P=0.002)$ were significant associated with increased glioma susceptibility. For rs2239670, compared with the carriers of genotype 
Table 3: Genotype frequencies of CART rs2239670, rs11575893 and association with risk of gliomas in stage II and the merged results

\begin{tabular}{|c|c|c|c|c|}
\hline & Cases $(n=800)$ & Controls $(\mathrm{n}=\mathbf{8 0 0})$ & $\mathrm{OR}^{1}(95 \%$ CIs) & $P$ value \\
\hline \multicolumn{5}{|l|}{ rs2239670 } \\
\hline \multicolumn{5}{|l|}{ Stage II } \\
\hline GG & 499 & 536 & Reference & \\
\hline $\mathrm{AG}$ & 251 & 232 & $1.16(0.94-1.44)$ & \\
\hline AA & 50 & 32 & $1.68(1.06-2.65)$ & \\
\hline Additive model & & & $1.24(1.04-1.47)$ & 0.015 \\
\hline \multicolumn{5}{|l|}{\begin{tabular}{|l|} 
Merged results \\
\end{tabular}} \\
\hline GG & 756 & 816 & Reference & \\
\hline $\mathrm{AG}$ & 366 & 336 & $1.17(0.98-1.40)$ & \\
\hline AA & 78 & 48 & $1.75(1.21-2.53)$ & \\
\hline Additive model & & & $1.27(1.10-1.46)$ & 0.001 \\
\hline \multicolumn{5}{|l|}{\begin{tabular}{|l} 
rs11575893 \\
\end{tabular}} \\
\hline \multicolumn{5}{|l|}{ Stage II } \\
\hline $\mathrm{CC}$ & 506 & 545 & Reference & \\
\hline $\mathrm{CT}$ & 250 & 225 & $1.20(0.96-1.49)$ & \\
\hline TT & 44 & 30 & $1.58(0.98-2.54)$ & \\
\hline Additive model & & & $1.23(1.04-1.47)$ & \begin{tabular}{|l|}
0.018 \\
\end{tabular} \\
\hline \multicolumn{5}{|l|}{ Merged results } \\
\hline $\mathrm{CC}$ & 752 & 815 & Reference & \\
\hline $\mathrm{CT}$ & 380 & 340 & $1.21(1.01-1.44)$ & \\
\hline TT & 68 & 45 & $1.64(1.11-2.41)$ & \\
\hline Additive model & & & $1.25(1.09-1.45)$ & 0.002 \\
\hline
\end{tabular}

${ }^{1}$ adjusted for Age, gender, family history of cancer, smoking status and alcohol status

Table 4: Stratified analyses of CART rs2239670, rs11575893 with risk of gliomas

\begin{tabular}{|c|c|c|c|c|}
\hline & \multicolumn{2}{|l|}{ rs2239670 } & \multicolumn{2}{|l|}{ rs11575893 } \\
\hline & OR $^{1}(95 \%$ CIs) & $P$ value & $\mathrm{OR}^{1}(95 \% \mathrm{CIs})$ & $P$ value \\
\hline \multicolumn{5}{|c|}{ Smoking status } \\
\hline Ever & $1.27(0.92-1.74)$ & 0.143 & $1.25(0.91-1.72)$ & 0.161 \\
\hline Never & $1.27(1.08-1.48)$ & 0.004 & $1.25(1.07-1.47)$ & 0.005 \\
\hline \multicolumn{5}{|c|}{ Alcohol status } \\
\hline Ever & $1.27(0.95-1.68)$ & 0.104 & $1.25(0.94-1.67)$ & 0.120 \\
\hline Never & $1.27(1.07-1.49)$ & 0.005 & $1.25(1.06-1.48)$ & 0.007 \\
\hline
\end{tabular}

${ }^{1}$ adjusted for Age, gender, and family history of cancer

GG, those of genotype AA (OR $=1.75 ; 95 \% \mathrm{CI}=1.21$ 2.53) had significantly increased glioma susceptibility. While for rs11575893, compared with the carriers of genotype $\mathrm{CC}$, both those of genotype $\mathrm{CT}(\mathrm{OR}=1.21$; $95 \% \mathrm{CI}=1.01-1.44)$ and $\mathrm{TT}(\mathrm{OR}=1.64 ; 95 \% \mathrm{CI}=1.11$ 2.41) had significantly increased glioma susceptibility. We also explored the effect modification of alcohol status and smoking status (Table 4), however, the results didn't change materially.

\section{DISCUSSION}

In this study, a two-stage, case-control study was applied to systematically evaluated whether genetic variants of CART gene contribute to susceptibility of gliomas among Chinese population. We identified that both rs2239670 and rs11575893 were significant associated with increased glioma susceptibility. To our knowledge, this should be the first study which aims to evaluated the association between genetic variants of CART gene and susceptibility of gliomas.

Except that exposure to ionizing radiation has been 
established as a risk factor, most underlying cause for gliomas has not been identified [26-30]. Genetic factors, which have been explored for many decades, play an essential roles in the development of gliomas and are key component of preventive oncology, however, only a small proportion of the genetic effect has been yet established [1, 14, 31-34]. CART gene is located at 5q13.2 in humans, and is expressed in diverse brain structures, as well as endocrine tissues [35]. In 1999, Echwald et al first evaluated the potential effect of sequence variants CART gene in subjects with early onset obesity [25]. It was also found that hypothalamic CART expression could be involved a variety of neuroendocrine functions including food-intake [36]. Furthermore, CART gene was identified to be related with type 2 diabetes mellitus, hormone release, breast cancer, small bowel carcinoid tumors, neuroendocrine tumor, and so on [37-43].

In this study, we confirmed rs2239670 (Allele A vs $\mathrm{G}: \mathrm{OR}=1.27 ; 95 \% \mathrm{CI}=1.10-1.46 ; P=0.001)$ and rs 11575893 (Allele T vs $\mathrm{C}: \mathrm{OR}=1.25 ; 95 \% \mathrm{CI}=1.09$ $1.45 ; P=0.002)$ were significant associated with increased glioma susceptibility. SNP rs11575893 is located at the 3' UTR region of the CART gene, while rs2239670 is an intronic variant. Using RegulomeDB [44, 45], both scores of rs2239670 and rs11575893 was identified to be 4, which means the SNPs could affect TF binding and DNase peak. When analyzed by HaploReg v4.1 [46], results showed that rs2239670 could alter regulatory motifs, including TATA, YY1,ZBTB7A, and could bind proteins including NRSF, HDAC2, RAD21 SIN3AK20, and ZNF263.
While for rs11575893, motifs GCNF,Hand1,Myc could be changed, and it also could bind NRSF, ZNF263, and SIN3AK20. NRSF and ZNF263 are important modulator of malignant progression [47, 48]. Overall, our findings provided evidence for the important role of SNPs in CART gene in the tumorigenesis of gliomas.

Our study has several strengths. First, the two-stage study design provides a solid and trustable conclusion; second, the large sample size provides enough statistical power to detect such moderate associations. When interpreting the results of this study, several limitations should also be considered. First, selection and information bias might be unavoidable due to the natural of casecontrol study design, although the controls have been matched by age, gender, and race. Second, we still have not enough sample size to detect gene-environment interactions in current study. Third, it is uncertain whether our findings can be generalized to other populations due to the samples recruited in this study was restricted to Chinese population.

In conclusion, this study found that both CART rs2239670 and rs11575893 were significant associated with increased glioma risk using a two-stage, case-control study with a large sample size. The results suggest that the rs2239670 and rs11575893 may be used as biomarkers for prediction and screening of lung cancer. Validations with larger population-based studies in different ethnic groups and mechanism studies are warranted to further interpret the findings.

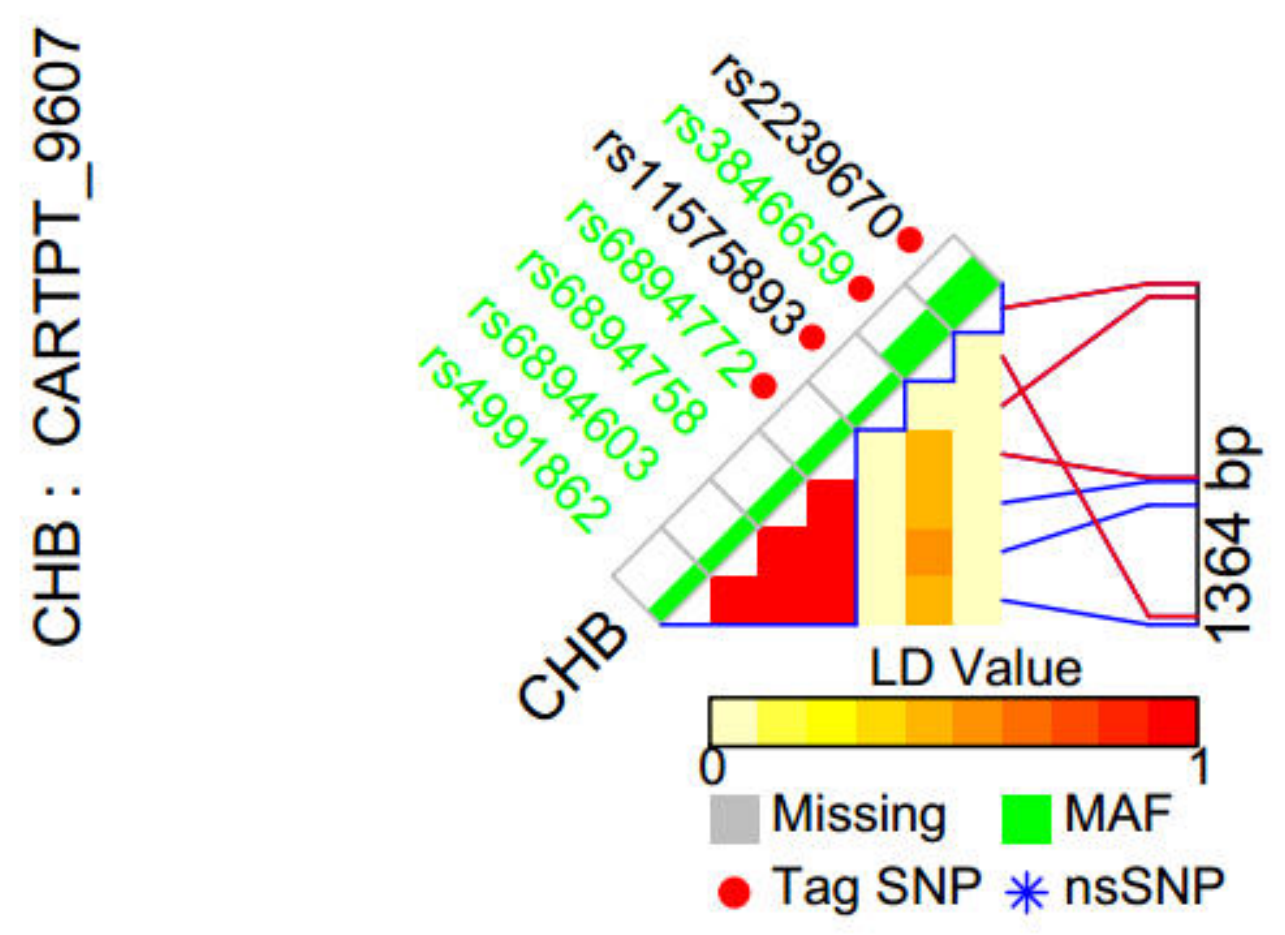

Figure 1: 


\section{MATERIALS AND METHODS}

\section{Subjects}

Totally included in this study were 1,200 genetically unrelated gliomas cases from Tangdu Hospital, which were newly diagnosed and histopathologically confirmed patients until November 2015, as well as a total of 1,200 age-, gender-, race-matched, cancer-free healthy controls which were recruited from the same hospital at the same period. All the participants have no previous history of cancer and CNS-related diseases. Face to face interviews were performed using unified questionnaires to collect data on demographic characteristics and potential glioma susceptibility factors. After the interview, $5 \mathrm{ml}$ peripheral blood sample were collected for each participant. The study protocol was approved by the Institutional Review Board of Tangdu Hospital and all of the participants provided written informed consent by themselves or their guardians.

\section{SNP selection and genotyping}

The tag SNPs of CART gene and its $1 \mathrm{~kb}$ flanking region were selected using SNPinfo (http://snpinfo. niehs.nih.gov/) based on the criteria of minor allele frequency(MAF) $>5 \%$ for Chinese Han subjects; Four tag SNPs in the CART gene that met the criteria were chosen in this study (Figure 1). Genomic DNAs were extracted by Qiagen DNA blood kit following the manufacturer's protocols. The SNP genotyping was performed by Sequenom MassArray iPLEX platform (Sequenom Inc., San Diego, CA, USA). Approximately $10 \%$ of the samples were randomly selected and genotyped with sequencing to validate the accuracy of genotyping results. A concordance of $100 \%$ for the quality control samples confirmed the liability of the Sequenom MassArray iPLEX platform.

\section{Statistical analyses}

The difference in gender, family history of cancer, smoking status and alcohol status between gliomas patients and healthy controls were evaluated using the chi-square test, while the difference in age between gliomas patients and healthy controls were tested by student's paired $t$ test. Goodness-of-fit $\chi 2$ test were used to evaluate the potential departure from Hardy-Weinberg equilibrium (HWE) of genotypic frequencies in controls for each SNP. Odds ratios and corresponding 95\% confidence intervals (CIs) were used to estimate the association between selected polymorphisms and glioma susceptibility. Adjusted ORs by age, gender, family history of cancer, smoking status and alcohol status were calculated using multivariate analysis with unconditional logistic regression. All the data was analyzed with SPSS software version 13.0 (SPSS Inc, Chicago, IL, USA). All statistical tests were twosided, with a significance level of $P<0.05$.

\section{CONFLICTS OF INTEREST}

The authors declare no competing financial interests.

\section{GRANT SUPPORT}

This work was supported by National Natural Scientific Foundation of China (NO. 81272419, NO. 81572983, NO. 81402081, NO. 81572697, NO. 81272776), Social development, science and technology research projects Of Shaanxi Province (2015SF027, 2016SF191) and Open Funding of Laboratory of Brain Disorders, Ministry of Science and Technology (2015NZDJ02).

\section{REFERENCES}

1. Goodenberger ML, Jenkins RB. Genetics of adult glioma. Cancer Genet. 2012; 205:613-21. https://doi.org/10.1016/j. cancergen.2012.10.009

2. Meyer MA. Malignant gliomas in adults. N Engl J Med. 2008; 359:1850. https://doi.org/10.1056/NEJMc086380

3. Wen PY, Kesari S. Malignant gliomas in adults. N Engl J Med. 2008; 359:492-507. https://doi.org/10.1056/ NEJMra0708126

4. Cheng Y, Tu Y, Liang P. Promoter Methylated Tumor Suppressor Genes in Glioma. Cancer Transl Med. 2015; 1:123-30. https://doi.org/10.4103/2395-3977.163803

5. Qi J, Yang H, Wang X, Tu Y. The progress in molecular biomarkers of gliomas. Cancer Transl Med. 2016; 2:12529. https://doi.org/10.4103/2395-3977.189305

6. Chen W, Zheng R, Baade PD, Zhang S, Zeng H, Bray F, Jemal A, Yu XQ, He J. Cancer statistics in China, 2015. CA Cancer J Clin. 2016; 66:115-32. https://doi.org/10.3322/ caac. 21338

7. Siegel RL, Miller KD, Jemal A. Cancer statistics, 2016. CA Cancer J Clin. 2016; 66:7-30. https://doi.org/10.3322/ caac. 21332

8. Walsh KM, Codd V, Rice T, Nelson CP, Smirnov IV, McCoy LS, Hansen HM, Elhauge E, Ojha J, Francis SS, Madsen NR, Bracci PM, Pico AR, et al, and ENGAGE Consortium Telomere Group. Longer genotypicallyestimated leukocyte telomere length is associated with increased adult glioma risk. Oncotarget. 2015; 6:42468-77. https://doi.org/10.18632/oncotarget.6468

9. Heidenreich B, Rachakonda PS, Hosen I, Volz F, Hemminki K, Weyerbrock A, Kumar R. TERT promoter mutations and telomere length in adult malignant gliomas and recurrences. Oncotarget. 2015; 6:10617-33. https://doi.org/10.18632/ 
oncotarget.3329

10. Chan AK, Yao Y, Zhang Z, Shi Z, Chen L, Chung NY, Liu JS, Li KK, Chan DT, Poon WS, Wang Y, Zhou L, Ng HK. Combination genetic signature stratifies lower-grade gliomas better than histological grade. Oncotarget. 2015; 6:20885-901. https://doi.org/10.18632/oncotarget.4928

11. Killela PJ, Pirozzi CJ, Healy P, Reitman ZJ, Lipp E, Rasheed BA, Yang R, Diplas BH, Wang Z, Greer PK, Zhu $\mathrm{H}$, Wang CY, Carpenter AB, et al. Mutations in IDH1, IDH2, and in the TERT promoter define clinically distinct subgroups of adult malignant gliomas. Oncotarget. 2014; 5:1515-25. https://doi.org/10.18632/oncotarget.1765

12. Kinnersley B, Labussière M, Holroyd A, Di Stefano AL, Broderick P, Vijayakrishnan J, Mokhtari K, Delattre JY, Gousias K, Schramm J, Schoemaker MJ, Fleming SJ, Herms S, et al. Genome-wide association study identifies multiple susceptibility loci for glioma. Nat Commun. 2015; 6:8559. https://doi.org/10.1038/ncomms9559

13. Walsh KM, Codd V, Smirnov IV, Rice T, Decker PA, Hansen HM, Kollmeyer T, Kosel ML, Molinaro AM, McCoy LS, Bracci PM, Cabriga BS, Pekmezci M, et al, and ENGAGE Consortium Telomere Group. Variants near TERT and TERC influencing telomere length are associated with high-grade glioma risk. Nat Genet. 2014; 46:731-35. https://doi.org/10.1038/ng.3004

14. Ostrom QT, Bauchet L, Davis FG, Deltour I, Fisher JL, Langer CE, Pekmezci M, Schwartzbaum JA, Turner MC, Walsh KM, Wrensch MR, Barnholtz-Sloan JS. The epidemiology of glioma in adults: a "state of the science" review. Neuro-oncol. 2014; 16:896-913. https://doi. org/10.1093/neuonc/nou087

15. Labussière M, Di Stefano AL, Gleize V, Boisselier B, Giry M, Mangesius S, Bruno A, Paterra R, Marie Y, Rahimian A, Finocchiaro G, Houlston RS, Hoang-Xuan K, et al. TERT promoter mutations in gliomas, genetic associations and clinico-pathological correlations. Br J Cancer. 2014; 111:2024-32. https://doi.org/10.1038/bjc.2014.538

16. Zhang J, Wu G, Miller CP, Tatevossian RG, Dalton JD, Tang B, Orisme W, Punchihewa C, Parker M, Qaddoumi I, Boop FA, Lu C, Kandoth C, et al, and St. Jude Children's Research Hospital-Washington University Pediatric Cancer Genome Project. Whole-genome sequencing identifies genetic alterations in pediatric low-grade gliomas. Nat Genet. 2013; 45:602-12. https://doi.org/10.1038/ng.2611

17. Yermolaieva O, Chen J, Couceyro PR, Hoshi T. Cocaineand amphetamine-regulated transcript peptide modulation of voltage-gated $\mathrm{Ca} 2+$ signaling in hippocampal neurons. J Neurosci. 2001; 21:7474-80.

18. Couceyro P, Paquet M, Koylu E, Kuhar MJ, Smith $Y$. Cocaine- and amphetamine-regulated transcript (CART) peptide immunoreactivity in myenteric plexus neurons of the rat ileum and co-localization with choline acetyltransferase. Synapse. 1998; 30:1-8. https://doi. org/10.1002/(SICI)1098-2396(199809)30:1<1::AID$\mathrm{SYN} 1>3.0 . \mathrm{CO} ; 2-7$
19. Koylu EO, Couceyro PR, Lambert PD, Kuhar MJ. Cocaine- and amphetamine-regulated transcript peptide immunohistochemical localization in the rat brain. $\mathrm{J}$ Comp Neurol. 1998; 391:115-32. https://doi.org/10.1002/ (SICI)1096-9861(19980202)391:1<115::AIDCNE10>3.0.CO;2-X

20. Mo C, Cai G, Huang L, Deng Q, Lin D, Cui L, Wang Y, Li J. Corticotropin-releasing hormone (CRH) stimulates cocaine- and amphetamine-regulated transcript gene (CART1) expression through $\mathrm{CRH}$ type 1 receptor (CRHR1) in chicken anterior pituitary. Mol Cell Endocrinol. 2015; 417:166-77. https://doi.org/10.1016/j. mce.2015.09.007

21. Lisa Y, Sook- HF, Yee- HS. Association of the Cocaineand Amphetamine-Regulated Transcript Prepropeptide Gene (CARTPT) rs2239670 Variant with Obesity among Kampar Health Clinic Patrons, Malaysia. Malays J Med Sci. 2012; 19:43-51.

22. Wang PQ, Deng LM, Zhang BY, Chu MX, Hou JZ. Polymorphisms of the cocaine-amphetamine-regulated transcript (CART) gene and their association with reproductive traits in Chinese goats. Genet Mol Res. 2011; 10:731-38. https://doi.org/10.4238/vol10-2gmr1091

23. Busto A, Souza RP, Lobo DS, Shaikh SA, Zawertailo LA, Busto UE, Kennedy JL. Cocaine and amphetamine regulated transcript (CART) gene in the comorbidity of schizophrenia with alcohol use disorders and nicotine dependence. Prog Neuropsychopharmacol Biol Psychiatry. 2010; 34:834-36. https://doi.org/10.1016/j.pnpbp.2010.03.030

24. Jung SK, Hong MS, Suh GJ, Jin SY, Lee HJ, Kim BS, Lim YJ, Kim MK, Park HK, Chung JH, Yim SV. Association between polymorphism in intron 1 of cocaine- and amphetamine-regulated transcript gene with alcoholism, but not with bipolar disorder and schizophrenia in Korean population. Neurosci Lett. 2004; 365:54-57. https://doi. org/10.1016/j.neulet.2004.04.036

25. Echwald SM, Sørensen TI, Andersen T, Hansen C, Tommerup N, Pedersen O. Sequence variants in the human cocaine and amphetamine-regulated transcript (CART) gene in subjects with early onset obesity. Obes Res. 1999; 7:532-36. https://doi.org/10.1002/j.1550-8528.1999. tb00710.x

26. Advani SJ, Markert JM, Sood RF, Samuel S, Gillespie GY, Shao MY, Roizman B, Weichselbaum RR. Increased oncolytic efficacy for high-grade gliomas by optimal integration of ionizing radiation into the replicative cycle of HSV-1. Gene Ther. 2011; 18:1098-102. https://doi. org/10.1038/gt.2011.61

27. Newcomb EW, Demaria S, Lukyanov Y, Shao Y, Schnee T, Kawashima N, Lan L, Dewyngaert JK, Zagzag D, McBride WH, Formenti SC. The combination of ionizing radiation and peripheral vaccination produces long-term survival of mice bearing established invasive GL261 gliomas. Clin Cancer Res. 2006; 12:4730-37. https://doi. org/10.1158/1078-0432.CCR-06-0593 
28. Bradley JD, Kataoka Y, Advani S, Chung SM, Arani RB, Gillespie GY, Whitley RJ, Markert JM, Roizman B, Weichselbaum RR. Ionizing radiation improves survival in mice bearing intracranial high-grade gliomas injected with genetically modified herpes simplex virus. Clin Cancer Res. 1999; 5:1517-22.

29. Apuzzo ML, Jepson JH, Luxton G, Little FM. Ionizing and nonionizing radiation treatment of malignant cerebral gliomas: specialized approaches. Clin Neurosurg. 1983; 31:470-96. https://doi.org/10.1093/neurosurgery/31.CN suppl_1.470

30. Mungyerova G, Kuzma I, Jacz K. The Effect of Ionizing Radiation on the Biological Activity of Gliomas. Neoplasma. 1965; 12:285-88.

31. Pekmezci M, Perry A. Genetic markers in adult high-grade gliomas. Semin Radiat Oncol. 2014; 24:235-39. https://doi. org/10.1016/j.semradonc.2014.06.005

32. Hambardzumyan D, Parada LF, Holland EC, Charest A. Genetic modeling of gliomas in mice: new tools to tackle old problems. Glia. 2011; 59:1155-68. https://doi. org/10.1002/glia.21142

33. Palanichamy K, Erkkinen M, Saia G, Chakravarti A. Molecular and genetic profiling in human gliomas. Discov Med. 2007; 7:75-81.

34. Ohgaki H, Kleihues P. Epidemiology and etiology of gliomas. Acta Neuropathol. 2005; 109:93-108. https://doi. org/10.1007/s00401-005-0991-y

35. Douglass J, Daoud S. Characterization of the human cDNA and genomic DNA encoding CART: a cocaine- and amphetamine-regulated transcript. Gene. 1996; 169:241-45. https://doi.org/10.1016/0378-1119(96)88651-3

36. Charnay Y, Perrin C, Vallet PG, Greggio B, Kovari E, Bouras C. Mapping of cocaine and amphetamine regulated transcript (CART) mRNA expression in the hypothalamus of elderly human. J Chem Neuroanat. 1999; 17:123-28. https://doi.org/10.1016/S0891-0618(99)00028-9

37. Fu M, Cheng H, Chen L, Wu B, Cai M, Xie D, Fu Z. [Association of the cocaine and amphetamine-regulated transcript gene with type 2 diabetes mellitus]. Zhonghua Nei Ke Za Zhi. 2002; 41:805-08.

38. Baranowska B, Wolińska-Witort E, Martyńska L, Chmielowska M, Baranowska-Bik A. Effects of cocaineamphetamine regulated transcript (CART) on hormone release. Regul Pept. 2004; 122:55-59. https://doi. org/10.1016/j.regpep.2004.05.006

39. Brennan DJ, O'Connor DP, Laursen H, McGee SF, McCarthy S, Zagozdzon R, Rexhepaj E, Culhane AC, Martin FM, Duffy MJ, Landberg G, Ryden L, Hewitt $\mathrm{SM}$, et al. The cocaine- and amphetamine-regulated transcript mediates ligand-independent activation of ER $\alpha$, and is an independent prognostic factor in node-negative breast cancer. Oncogene. 2012; 31:3483-94. https://doi. org/10.1038/onc.2011.519

40. Landerholm K, Shcherbina L, Falkmer SE, Järhult J,
Wierup N. Expression of cocaine- and amphetamineregulated transcript is associated with worse survival in small bowel carcinoid tumors. Clin Cancer Res. 2012; 18:3668-76. https://doi.org/10.1158/1078-0432.CCR-112513

41. Burgos JR, Iresjö BM, Smedh U. MCG101-induced cancer anorexia-cachexia features altered expression of hypothalamic Nucb2 and Cartpt and increased plasma levels of cocaine- and amphetamine-regulated transcript peptides. Oncol Rep. 2016; 35:2425-30. https://doi.org/10.3892/ or.2016.4558

42. Ramachandran R, Bech P, Murphy KG, Caplin ME, Patel M, Vohra S, Khan MS, Dhillo WS, Sharma R, Palazzo FF, Win Z, Tan T, Khoo B, et al. Comparison of the utility of Cocaine- and Amphetamine-Regulated Transcript (CART), chromogranin A, and chromogranin B in neuroendocrine tumor diagnosis and assessment of disease progression. $\mathrm{J}$ Clin Endocrinol Metab. 2015; 100:1520-28. https://doi. org/10.1210/jc.2014-3640

43. Nakhate KT, Kokare DM, Singru PS, Taksande AG, Kotwal SD, Subhedar NK. Hypothalamic cocaine- and amphetamine-regulated transcript peptide is reduced and fails to modulate feeding behavior in rats with chemicallyinduced mammary carcinogenesis. Pharmacol Biochem Behav. 2010; 97:340-49. https://doi.org/10.1016/j. pbb.2010.09.001

44. Lee SY, Hong MJ, Jeon HS, Choi YY, Choi JE, Kang HG, Jung DK, Jin C, Do SK, Yoo SS, Seok Y, Lee EB, Shin KM, et al. Functional intronic ERCC1 polymorphism from regulomeDB can predict survival in lung cancer after surgery. Oncotarget. 2015; 6:24522-32. https://doi. org/10.18632/oncotarget.4083

45. Boyle AP, Hong EL, Hariharan M, Cheng Y, Schaub MA, Kasowski M, Karczewski KJ, Park J, Hitz BC, Weng S, Cherry JM, Snyder M. Annotation of functional variation in personal genomes using RegulomeDB. Genome Res. 2012; 22:1790-97. https://doi.org/10.1101/gr.137323.112

46. Ward LD, Kellis M. HaploReg v4: systematic mining of putative causal variants, cell types, regulators and target genes for human complex traits and disease. Nucleic Acids Res. 2016; 44:D877-81. https://doi.org/10.1093/nar/ gkv1340

47. Kreisler A, Strissel PL, Strick R, Neumann SB, Schumacher U, Becker CM. Regulation of the NRSF/REST gene by methylation and CREB affects the cellular phenotype of small-cell lung cancer. Oncogene. 2010; 29:5828-38. https://doi.org/10.1038/onc.2010.321

48. Yang YH, Markus MA, Mangs AH, Raitskin O, Sperling R, Morris BJ. ZRANB2 localizes to supraspliceosomes and influences the alternative splicing of multiple genes in the transcriptome. Mol Biol Rep. 2013; 40:5381-95. https://doi. org/10.1007/s11033-013-2637-9 